\title{
Induction of apoptosis by the novel retinoid AHPN in human T-cell lymphoma cells involves caspase-dependent and independent pathways
}

\author{
Hiroshi Adachi ${ }^{1}$, Anthony Adams ${ }^{1}$, Francis M. Hughes ${ }^{2}$, \\ Jiandi Zhang ${ }^{3}$, John A. Cidlowski ${ }^{2}$ and Anton M. Jetten ${ }^{1,4}$ \\ ${ }^{1}$ Cell Biology Section, Laboratory of Pulmonary Pathobiology, National Institute \\ of Environmental Health Sciences, National Institutes of Health, Research \\ Triangle Park, North Carolina 27709, USA \\ 2 Molecular Endocrinology Section, Laboratory of Signal Transduction, National \\ Institute of Environmental Health Sciences, National Institutes of Health, \\ Research Triangle Park, North Carolina 27709, USA \\ 3 Program in Molecular Medicine, Duke University Medical Center, Durham, \\ North Carolina 27710, USA \\ ${ }^{4}$ corresponding author: tel: 919-541-2768; fax: 919-541-4133; \\ e-mail: jetten@niehs.nih.gov
}

Received 27.3.98; revised 20.7.98; accepted 10.8.98 Edited by C.J.Thiele

\begin{abstract}
Retinoids play an important role in the control of lymphocyte function and homeostasis in the thymus. In this study, we show that the induction of growth arrest and apoptosis in a variety of T-cell lymphoma cell lines, including Jurkat and Molt- 4 cells, is highly specific for the synthetic retinoid 6-[3-(1-adamantyl)-4hydroxyphenyl]-2-naphthalene carboxylic acid (AHPN) since all-trans retinoic acid (RA), the RAR-selective retinoid TTAB, the RXR-selective retinoid SR11217 and the retinoid SR11302 exhibiting selective anti-AP1 activity, do not induce apoptosis or cause growth arrest. These findings support the concept that the effects of AHPN on proliferation and induction of apoptosis are mediated by a novel signaling pathway. AHPNinduced apoptosis is associated with an induction of internucleosomal DNA-fragmentation, increased annexin V binding and a 30 -fold stimulation of caspase-3-like activity. Overexpression of Bcl-2 in Molt-4 cells greatly inhibits the induction of apoptosis by AHPN as indicated by the inhibition of DNA-fragmentation, annexin V binding and caspase-3-like activity. However, Bcl-2 overexpression does not interfere with the ability of AHPN to cause growth arrest or accumulation of cells in the early S-phase of the cell cycle, indicating that the effects of AHPN on growth arrest can be uncoupled from the effects on apoptosis. The caspase inhibitor Z-VAD-FMK, at concentrations that totally block caspase activity, delays but does not prevent cell death and does not affect the accumulation of cells in the S-phase of the cell cycle. Our results show that induction of caspase-3-like activity plays an important role in the execution of AHPN-induced apoptosis but cells can undergo cell death in the absence of this activity suggesting that AHPN-induced cell death involves caspasedependent and -independent mechanisms.
\end{abstract}

Keywords: retinoids; apoptosis; lymphoma; caspase; cell proliferation

Abbreviations: AHPN, 6-[3-(1-adamantyl)-4-hydroxyphenyl]-2naphthalene carboxylic acid; RAR, retinoic acid receptor; RXR, retinoid $X$ receptor; PARP, poly(ADP-ribose)polymerase; MTT, 3(4,5-dimethylthiazol-2yl)-2,5-diphenyl tetrazolium bromide; RA, retinoic acid

\section{Introduction}

Apoptosis plays an important role in morphogenesis during normal embryonic development, homeostasis in many tissues in the adult and in the downmodulation of immune responses (Webb et al, 1997; Mountz et al, 1996; Jacobson et al, 1997). Defects in the control of apoptosis have been linked to numerous pathological processes, including cancer, autoimmune and neurodegenerative diseases (Thompson, 1995; Jacobson et al, 1997; Webb et al, 1997).

Programmed cell death is a multi-step process and an increasing number of genes have been identified that are involved in either the control or execution of apoptosis (Boise et al, 1995; Korsmeyer, 1995; Kumar and Flavin, 1996; Kroemer, 1997). One set of genes involved in cell death encode structurally-related cysteine proteases, named caspases, which cleave specific Asp-X peptide bonds (Nicholson, 1994; Fernandez-Alnemri et al, 1994; Kumar and Flavin, 1996). All known members of this family are synthesized as single-chain proenzymes which require proteolytic processing to produce active, heterodimeric proteases. Activation of caspases plays a critical role in the execution of apoptosis in T-lymphocytes and T-cell lymphomas as well as other cell types (Enari et al., 1996; Amstrong et al, 1996; Longthorne and Williams, 1997). Members of the Bcl-2 gene family encode another set of proteins that regulate apoptosis in either a positive or negative manner (Boise et al, 1995; Kroemer, 1997; Reed, 1997). Bcl-2 has been shown to inhibit the activation of caspases and protect $T$ cells from undergoing apoptosis in response to a variety of signals (Hockenbery et al, 1990; Miyashita and Reed, 1992; Zhang et al, 1996; Kroemer, 1997). Recent studies have indicated that the suppression of caspase activation by $\mathrm{Bcl}-2$ is related to inhibition of the release of cytochrome c from mitochondria (Kluck et al, 1997; Yang et al, 1997). However, cytochrome cindependent mechanisms of caspase activation have also been described (Chauhan et al, 1997).

T-lymphocytes have been used extensively as a model system to study apoptosis (Ucker, 1987, Smith et al, 1989; Mountz et al, 1996; Longthorne and Williams, 1997). Negative selection is a normal process in the thymus by 
which self-reactive $T$ cells undergo apoptosis after the interaction of the self-antigen with the $\mathrm{T}$ cell receptor and apoptosis can be induced by a number of other stimuli, including glucocorticoids, ceramide, irradiation, tumor necrosis factor, Fas ligand and anti-cancer drugs (Smith et al, 1989; Miyashita and Reed, 1992; Mountz et al, 1996; Zhang et al, 1996; Longthorne and Williams, 1997). Retinoids play also an important role in the control of homeostasis in the thymus and of lymphocyte function, and can effect proliferation and apoptosis in lymphocytes and lymphoma cells in either a positive or negative manner (Iwata et al, 1992; Vacchio and Ashwell, 1993; Yang et al, 1995a,b; O'Connell et al, 1996; Piedrafita and Pfahl, 1997; Szondy et al, 1997; Zhang and Jetten, 1997; Lomo et al, 1998). Many of the biological and molecular effects of retinoids are mediated by nuclear retinoid receptors (Giguère, 1994). The inhibition of activation-induced apoptosis by retinoids is due to an inhibition of Fas ligand mRNA synthesis and requires both RAR and RXR activation (Yang et al, 1995b; Bissonnette et al, 1995). In contrast, the inhibition of cell death in
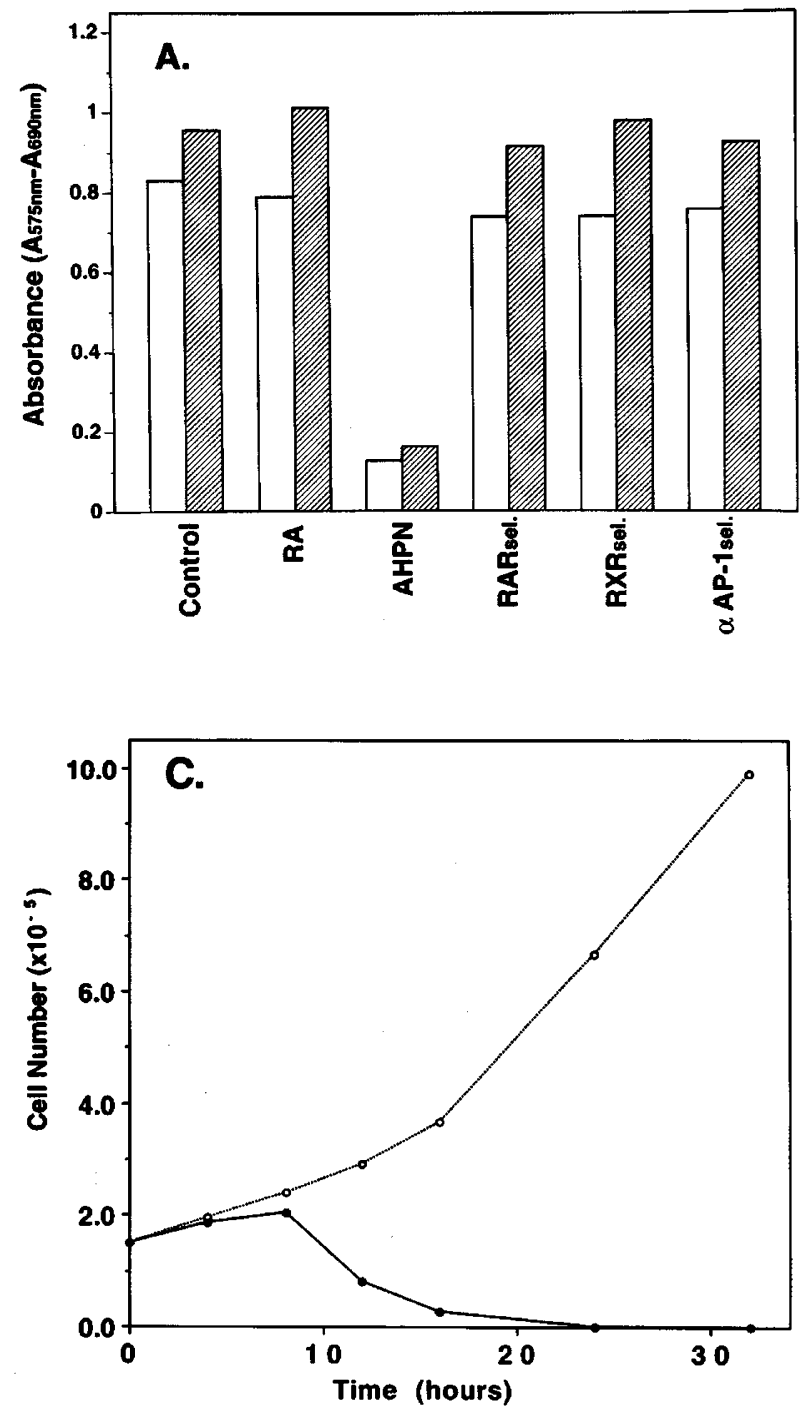

lymphocytes by 14-hydroxy-4,14-retroretinol is mediated through a mechanism not involving nuclear retinoid receptors (O'Connell et al, 1996). The inhibition of proliferation and induction of apoptosis in a variety of carcinoma cell lines by the synthetic retinoid 6-[3-(1-adamantyl)-4-hydroxyphenyl]-2-naphthalene carboxylic acid (AHPN) also occurs through a novel mechanism (Shao et al, 1995; Schadendorf et al, 1996; Oridate et al, 1997; Sun et al, 1997; Piedrafita and Pfahl, 1997; Hsu et al, 1997; Adachi et al, 1998).

$\mathrm{T}$ cell lymphocytes and lymphomas are excellent in vitro cell systems to study the signaling pathway by which AHPN induces apoptosis since the regulation of apoptosis in lymphocytes is well-studied and because of the important regulatory roles that various retinoids play in lymphocyte function. In this study, we demonstrate that the induction of growth arrest and apoptosis in a variety of $\mathrm{T}$ cell lymphoma cells, including Jurkat and Molt-4 cells, is highly specific for AHPN since all-trans retinoic acid, an RAR-, an RXR-, and an anti-AP-1-selective retinoid were unable to induce apoptosis or cause accumulation of cells in the early S-

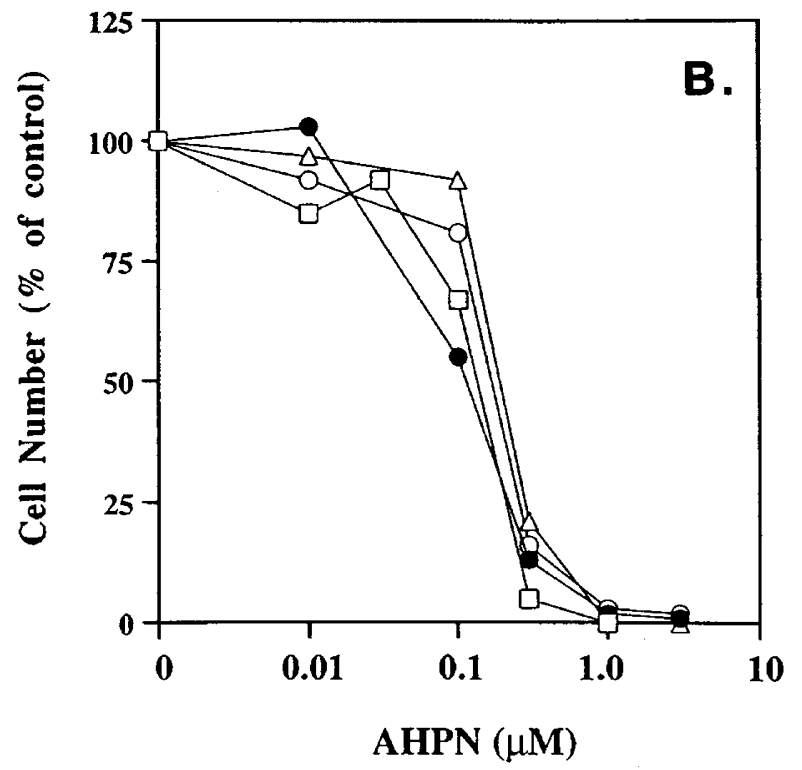

Figure 1 Effect of AHPN and several other retinoids on the proliferation of Jurkat, Molt-4 and S49-neo lymphoma cells and the T-cell hybridoma D011.10. (A) Comparison of effects of various retinoids on the growth of Molt- 4 and Jurkat cells. Cells were treated with $1 \mu \mathrm{M}$ of the indicated retinoid for 32 (Molt-4; hatched bars) or $24 \mathrm{~h}$ (Jurkat; open bars). Cell survival was determined with the MTT assay. The results shown are representative of two independent experiments. (B) Cells $\left(10^{5}\right.$ cells/well) were treated with AHPN at the concentrations indicated. After 4 days of incubation cell numbers were determined. $\square$, Jurkat; - S49-neo; $\triangle$, Molt-4; O, DO11.10 cells. (C). Effect of AHPN on cell survival of Jurkat cells as a function of the period of treatment. Cells were treated with $(0)$ and without $(O) 1 \mu \mathrm{M}$ AHPN and at the times indicated cells were stained with Trypan blue. The number of cells excluding Trypan blue (cell survival) was determined and plotted. The difference between duplicate cell numbers in $\mathbf{B}$ and $\mathbf{C}$ varied by no more than $5 \%$. Control cells received vehicle $(0.1 \%$ DMSO) only 
phase of the cell cycle. AHPN-induced apoptosis in T cell lymphomas is associated with an induction of DNA fragmentation, as indicated by 'ladder' and TUNEL assay, increased annexin $\mathrm{V}$ binding and caspase-3-like activity. The induction of caspase activity, annexin $\mathrm{V}$ binding and DNA fragmentation by AHPN but not growth arrest was inhibited in cells overexpressing Bcl-2 or cells treated with the caspase inhibitor Z-VAD-FMK. Our results suggest that although activation of caspases accelerate the execution of apoptosis, AHPN-induced cell death can occur independently of caspase activation.

\section{Results}

\section{AHPN-specific inhibition of cell proliferation}

Previous studies have reported that various retinoids can affect proliferation and apoptosis of lymphocytes and lymphoma cells in multiple ways and can influence these processes in a stimulatory as well as inhibitory manner (Yang et al, 1995a,b; Iwata et al, 1992; O'Connell et al, 1996; Szondy et al, 1997; Lomo et al, 1998). In this study, we examined the effects of several retinoid receptor-selective retinoids on the growth of the human $\mathrm{T}$ cell lymphoma cell lines Jurkat and Molt-4. The results show that the growthinhibitory effect was highly specific for AHPN since all-trans $R A$, the RAR-selective retinoid TTAB, the RXR-selective retinoid SR11217, and the anti-AP1-selective retinoid SR11302 had little effect on cell growth (Figure 1A). The growth-inhibitory effect could be observed at concentrations as low as $0.1 \mu \mathrm{M}$ AHPN and was not limited to Jurkat and Molt- 4 cells but could also be demonstrated in rat lymphoma S49 and the mouse T-cell hybridoma DO11.10 cells (Figure 1B). Combined treatment with RXR and RA, TTAB or AHPN did not further increase the effect on cell growth, and in contrast to normal thymocytes (Szondy et al, 1997), RAR $\alpha$ selective retinoids were unable to inhibit AHPN-induced apoptosis (not shown). To determine whether the growth inhibition by AHPN was related only to growth arrest or also involved cell death, cell survival in AHPN-treated Jurkat cells was monitored by a Trypan blue exclusion assay. After a lag of about $8 \mathrm{~h}$, AHPN caused a dramatic decrease in the viability of Jurkat cells indicating that AHPN induced cell death (Figure 1C).

\section{Induction of internucleosomal fragmentation by AHPN}

In order to determine whether the AHPN-induced reduction in cell viability in lymphoma cells was related to apoptosis, genomic DNA from AHPN-treated and untreated Jurkat and $S 49$ cells were isolated and examined for degradation into oligonucleosomal fragments by electrophoretic analysis. As shown in Figure 2, DNA from Jurkat and $S 49$ cells treated for $8 \mathrm{~h}$ with AHPN displayed an oligonucleosomal pattern of DNA degradation ('ladder') characteristic for apoptosis. DNA from dexamethasone-treated S49 cells was used as positive control for the induction of DNA fragmentation during apoptosis (Figure 2).
We next analyzed DNA fragmentation by the TdT dUTPFITC nick end-labeling (TUNEL) technique using flow cytometric analysis (Gavrieli et al, 1992). These analyses demonstrated that compared to control cells dUTP-FITC labeling was significantly increased in Jurkat cells treated for $8 \mathrm{~h}$ with AHPN (Figure 3, left panels). These results indicate that AHPN treatment results in increased formation of double-stranded DNA breaks and support AHPN-induced apoptosis in these cells.

\section{Induction of annexin V binding by AHPN}

In many cell types the induction of apoptosis is associated with plasma membrane changes including loss of membrane phospholipid asymmetry which can be analyzed by the translocation of phosphatidylserine from the inner layer of the plasma membrane to the outer layer (Vermes et al, 1995). The translocation of phosphatidylserine can be monitored by measuring the binding of FITC-conjugated annexin $\mathrm{V}, \mathrm{a} \mathrm{Ca}{ }^{2+}$ binding protein with high affinity for phosphatidylserine, to cells by flow cytometry. As shown in Figure 3 (right panels), treatment of Jurkat cells with AHPN dramatically increased the number of cells with high level of annexin V-FITC binding. Most of these appeared to represent cells in the intermediateto late-stage of apoptosis. These findings are consistent with the induction of apoptosis in lymphoma cells.

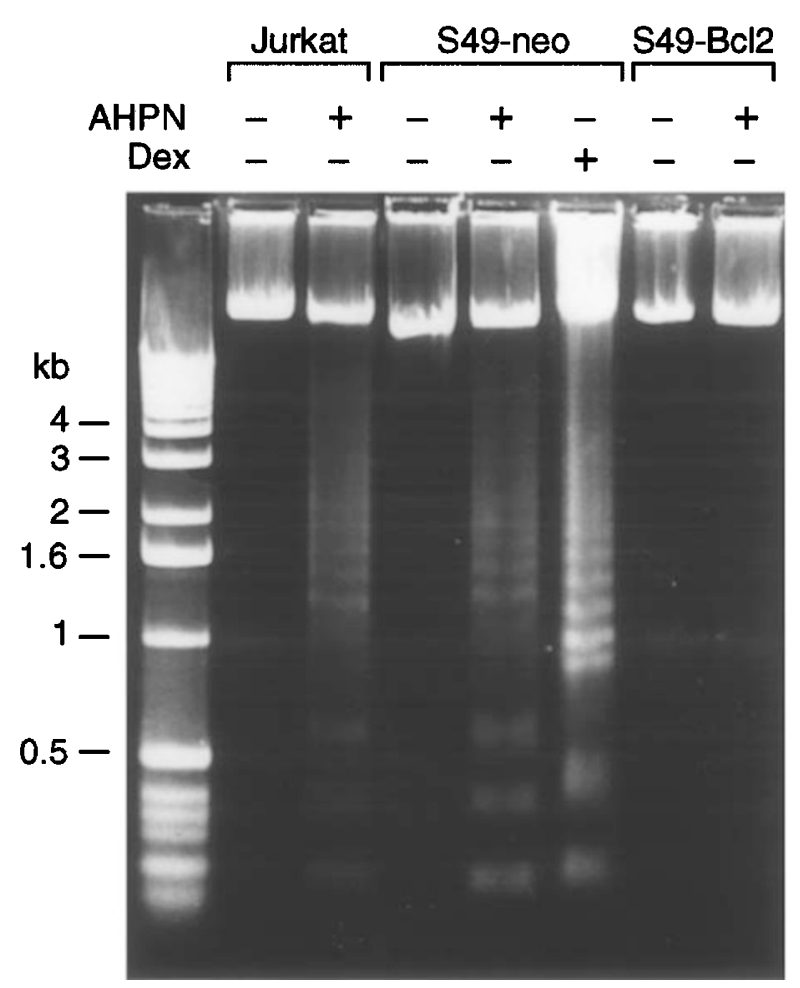

Figure 2 Oligonucleosomal degradation of genomic DNA in AHPN-treated Jurkat, S49-neo and S49-Bcl-2 cells. Cells were treated with $1 \mu \mathrm{M}$ AHPN and after $8 \mathrm{~h}$ DNA was isolated and analyzed by $1 \%$ agarose gel electrophoresis as described in Materials and Methods. Genomic DNA isolated from S49 cells treated with $0.3 \mu \mathrm{M}$ dexamethasone (Dex) for $24 \mathrm{~h}$ was included as a positive control. The size of the markers (left lane) is indicated in the left margin 

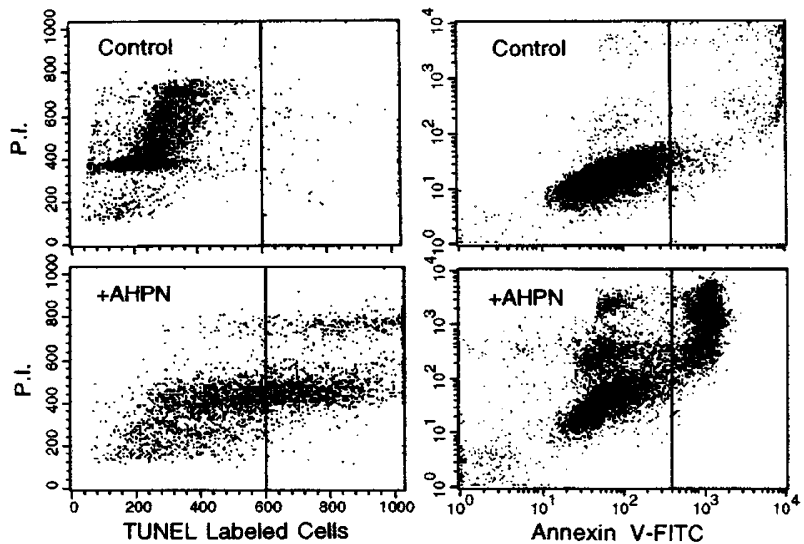

Figure 3 Induction of apoptosis by AHPN in Jurkat cells as indicated by TUNEL and annexin $V$ binding assays. (A, B) Cells were treated with DMSO (control) or $1 \mu \mathrm{M}$ AHPN for $8 \mathrm{~h}$. Cells were then fixed and analyzed for apoptosis with the nick end-labeling technique (TUNEL) by flow cytometry. (C, D) Increased annexin V-FITC binding in AHPN-treated Jurkat cells. Cells were treated with DMSO or $1 \mu \mathrm{M}$ AHPN for $8 \mathrm{~h}$. Cells were then analyzed for annexin V-FITC binding by flow cytometric analysis. (A, C): Control, DMSO-treated cells; (B, D): AHPN-treated cells. Vertical axis indicates relative propidium iodide $(\mathrm{PI})$ staining

\section{Induction of caspase-3-like activity by AHPN}

Activation of cysteine proteases is one of the key events in the induction of apoptosis (Nicholson 1994; Fernandes-Alnemri et al, 1994; Kumar and Flavin, 1996). To study the role of caspase activation in the AHPN-induced cell death pathway in lymphoma cells, we analyzed the activation of cysteine proteases by AHPN in Jurkat cells by determining the ability of cellular extracts to cleave the fluorogenic substrates YVADAFC or DEVD-AFC which are effective substrates for caspase-1-like and caspase-3-like proteases, respectively (Slee et al, 1996; Amstrong et al, 1996). As shown in Figure 4, extracts from control Jurkat and Molt-4 cells had relatively low proteolytic activity with either YVAD-AFC or DEVD-AFC as substrate. The basal caspase-3-like activity was higher in Molt-4 cells while caspase-1-like activity was higher in Jurkat cells. Extracts from AHPN-treated Jurkat and Molt-4 cells contained, respectively, 135- and 27-fold higher levels of DEVD-AFC cleaving activity than extracts from untreated cells while their ability to cleave YVAD-AFC was not much different from that of untreated cells. These results demonstrate that AHPN treatment dramatically induces caspase-3like activity and has little effect on caspase-1-like activity in these cells.

The induction of caspase-3-like activity by AHPN occurred in a time-dependent manner (Figure 5A). In Jurkat cells, caspase-3-like activity was induced after a lag-phase of about $4 \mathrm{~h}$. After $8 \mathrm{~h}$ the caspase-3-like activity was increased about 50 -fold. The induction of caspase activity was also dependent on the concentration of AHPN (Figure 5B). A sharp increase in caspase3-like activity was observed between 0.25 and $0.5 \mu \mathrm{M}$ AHPN.

To determine the specificity of this induction, we compared the effects of all-trans RA, AHPN, the RAR-,

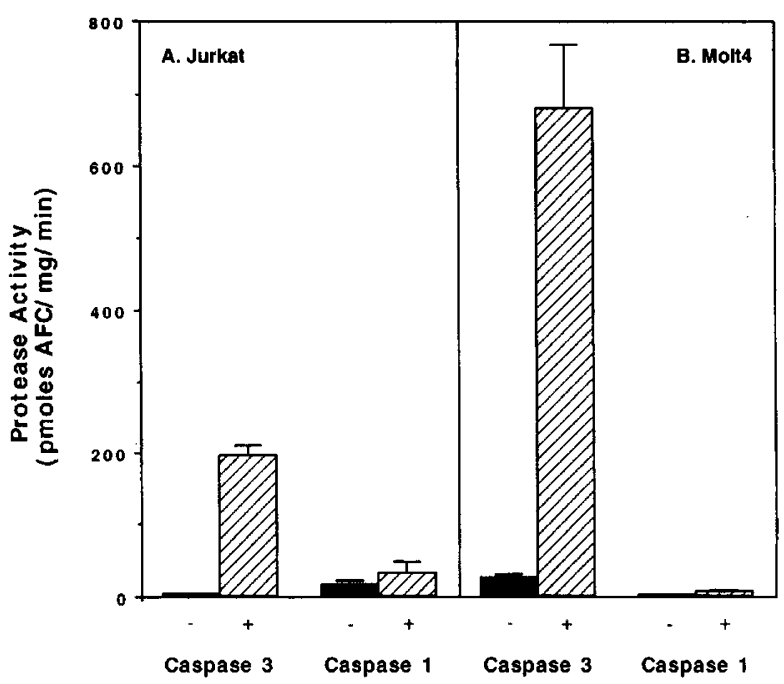

Figure 4 Effect of AHPN on the caspase-1- and caspase-3-like activity in Jurkat $(\mathbf{A})$ and Molt-4 cells (B). Cells were treated with $1 \mu \mathrm{M}$ AHPN $(+)$ or with solvent $(0.1 \% \mathrm{DMSO})(-)$ for $18 \mathrm{~h}$ and then assayed for caspase activity using either YVAD-AFC or DVED-AFC as substrate as described in Experimental Procedures. The experiment was performed in triplicate. Error bars indicate standard error
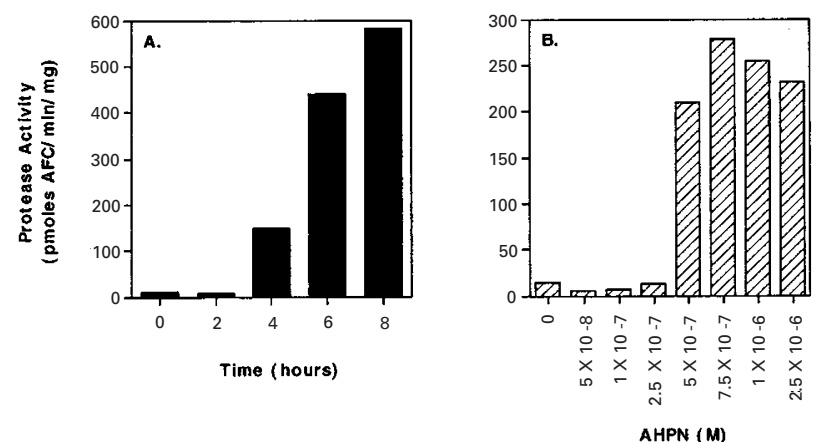

Figure 5 Time- and dose-dependent induction of caspase-3-like activity by AHPN in Jurkat cells. (A). Cells were treated with $1 \mu \mathrm{M}$ AHPN and at the indicated times cells were collected, lysed and cellular extracts assayed for caspase-3-like activity using DEVD-AFC as a substrate. The rate of DEVDAFC cleavage was determined and plotted as pmoles AFC $/ \mathrm{min} / \mathrm{mg}$ protein. (B). Cells were treated with AHPN at the concentrations indicated. After $6 \mathrm{~h}$ cells were collected and assayed for caspase-3-like activity

RXR- and anti-AP-1-selective retinoid on the induction of caspase-3-like activity (Figure 6A). Only AHPN was able to induce caspase-3-like activity in Jurkat cells. The specificity with which these retinoids induced caspase activity correlated with their ability to inhibit cell growth (Figure 1A). Previous studies have shown that RAR- and RXRselective retinoids can inhibit activation-induced apoptosis in $\mathrm{T}$ cell hybridomas by inhibiting the synthesis of Fas ligand (Yang et al, 1995a,b; Bissonnette et al, 1995). Therefore, we examined whether these retinoids could also inhibit the induction of apoptosis by AHPN. As shown in Figure $6 \mathrm{~B}$, neither the RXR-selective retinoid nor the RARselective retinoid TTAB affected caspase activation by AHPN in either a positive or negative manner. And in 


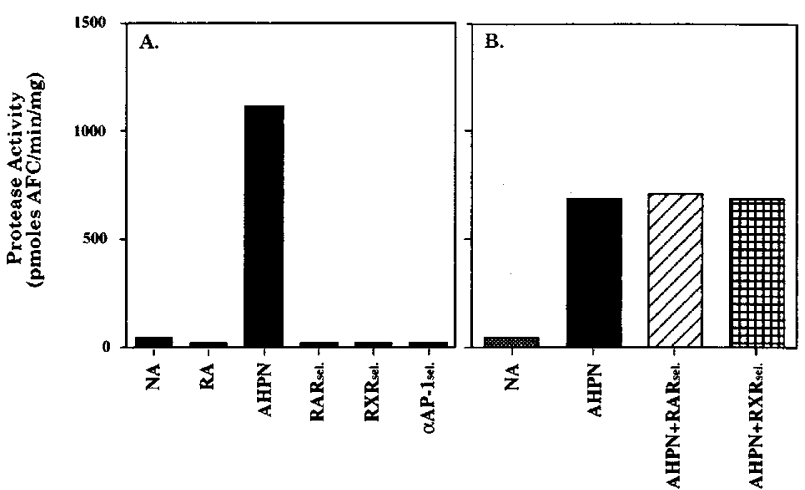

Figure 6 Induction of caspase-3-like activity is specific for AHPN. Jurkat cells were treated with $1 \mu \mathrm{M}$ all-trans RA, AHPN, an RAR-, RXR-, or an antiAP-1-selective retinoid $(\mathbf{A})$ or with a combination of AHPN and the RAR- or RXR-selective retinoid (B). After $6 \mathrm{~h}$ incubation cells were collected and assayed for caspase-3-like activity. The rate of DEVD-AFC cleavage was determined and plotted

contrast to thymocytes (Szondy et al, 1997), RAR $\alpha$ selective retinoids did not inhibit AHPN-induced apoptosis and simultaneous treatment with RXR- and RAR-selective retinoids did not induce caspase activity (not shown).

\section{Induction of PARP cleavage}

Poly(ADP-ribose)polymerase (PARP) is one of several proteins that have been identified to function as a substrate for caspases (Tewari et al, 1995; Kumar and Flavin, 1996). DEVD is the site of cleavage of the $113 \mathrm{kD}$ PARP by caspase3 yielding two fragments of 89 and $24 \mathrm{kD}$. We examined the ability of cellular extracts from AHPN-treated and untreated Molt- 4 cells to cleave a radiolabeled, truncated form of PARP (tPARP). As shown in Figure 7A, extracts from untreated cells contained only the $48 \mathrm{kD}$ tPARP while AHPN-treated cells contained in addition the 28 and $20 \mathrm{kD}$ cleaved products. The generation of these cleaved products was dependent on the time of AHPN-treatment.

\section{Effect of the caspase inhibitor Z-VAD-FMK on cell death}

Z-VAD-FMK is a cell-permeable peptide that at high concentrations irreversibly inhibits the activity of many caspases (Slee et al, 1996; Stefanis et al, 1996; Longthorne and Williams, 1997; Thornberry et al, 1997). To determine the effect of caspase inhibition on AHPN-induced cell death, we examined the relationship between the effect of increasing concentrations of Z-VAD-FMK on caspase activity and cell death in Molt- 4 cells. Z-VAD-FMK completely inhibited AHPNinduced caspase-3-like activity (Figure 8A) and caspase-1like activity (not shown) and also greatly reduced DNA fragmentation in AHPN-treated cells as measured by TUNEL analysis (Figure $8 \mathrm{~B}$ ). Despite the dramatic reduction in caspase activity and DNA-fragmentation, Z-VAD-FMK decreased but did not prevent AHPN-induced cell death (Figure $8 A)$. Similar observations have been reported for the action of Z-VAD-FMK on cell death induced by oncogenes, DNA

\section{A. MOLT-4}

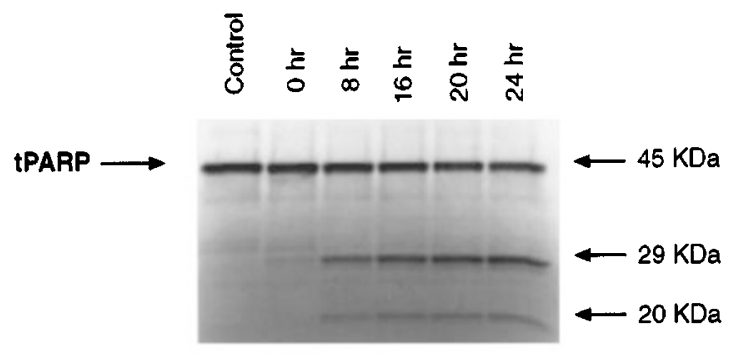

B. MOLT-bcl2

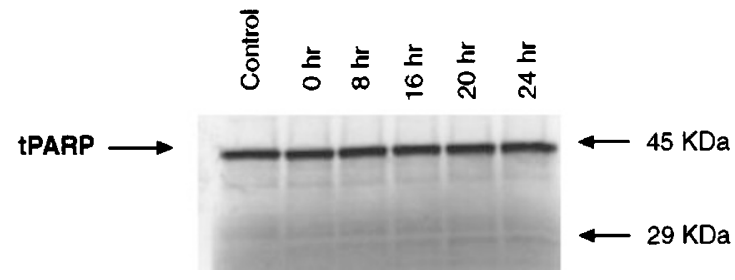

Figure 7 Comparison of the proteolytic cleavage of PARP by cellular extracts from AHPN-treated Molt-4-neo and Molt-4-Bcl-2 cells. Cell lysates prepared from cells treated with and without AHPN $(1 \mu \mathrm{M})$ were analyzed for their ability to cleave ${ }^{35} \mathrm{~S}$-labeled tPARP $(45 \mathrm{kD})$. The samples were subsequently analyzed by polyacrylamide gel electrophoresis, and fluorography performed. Cleavage products of 29 and $20 \mathrm{kD}$ are indicated by arrows

damage or the $\mathrm{Bcl}-2$ homologue Bak in rat fibroblasts (McCarthy et al, 1997) and Bax-induced cell death in Jurkat cells (Xiang et al, 1996). Z-VAD-FMK did not have any effect on the extent of the growth-inhibitory action of AHPN (Figure $8 \mathrm{~A})$. Flow cytometric analysis showed that treatment of Molt-4 cells with AHPN caused an accumulation of cells in the Sphase of the cell cycle. The presence of Z-VAD-FMK did not prevent this accumulation in the S-phase (not shown). These results suggest that growth arrest occurs independent of caspase activation and indicate that activation of caspase-3like activity is an important factor in the execution of AHPNinduced cell death and appears to act in parallel with other events that by themselves can result in cell death.

\section{Inhibition of apoptosis by $\mathrm{Bcl}-2$}

Members of the Bcl-2 family are major regulators of apoptosis (Korsmeyer, 1995; Kroemer, 1997; Reed, 1997). The induction of apoptosis by ceramide, Fas ligand, T cell antigen and dexamethasone in lymphocytes is inhibited by $\mathrm{Bcl}-2$ (Hockenbery et al, 1990; Miyashita and Reed, 1992; CaronLeslie et al, 1994; Zhang et al, 1996). We examined whether $\mathrm{Bcl}-2$ expression could also inhibit AHPN-induced apoptosis. Using Molt-4 cells stably transfected with Bcl-2 or the control vector, AHPN induced death in Molt-4-neo cells as measured by Trypan Blue exclusion while cell death was greatly reduced but not completely blocked in AHPN-treated Molt4-Bcl-2 cells (Figure 9A). The inhibition of AHPN-induced cell death by Bcl- 
2 could not be overcome by increasing AHPN concentrations (Figure 9B). Although Bcl-2 inhibited cell death, it did not block the growth-inhibitory effect of AHPN since treatment of Molt-4Bcl-2 with AHPN still caused accumulation of cells in the early S-phase of the cell cycle as observed for AHPN-treated Molt-4 cells (not shown). Treatment of Molt- 4 cells with AHPN did not alter the level of Bcl-2 mRNA or protein (not shown).

We next examined the effect of Bcl-2 on the AHPNinduced caspase-3-like activity in Molt-4-neo and Molt-4$\mathrm{Bcl}-2$ cells (Figure 10A). Bcl-2 greatly inhibited the activation of caspase-3-like activity by AHPN. In agree-
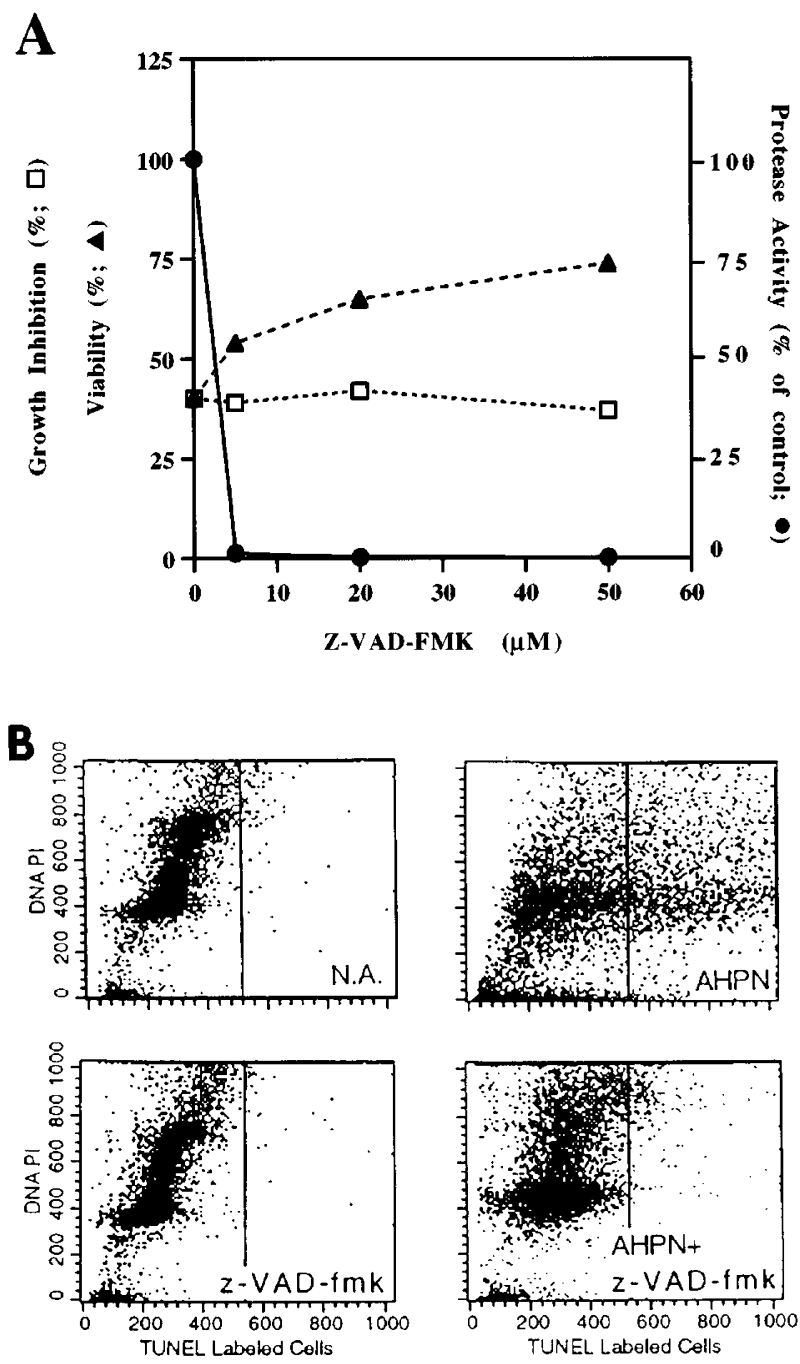

Figure 8 Effect of Z-VAD-FMK on the inhibition of cell proliferation, induction of caspase-3-like activity, cell viability and DNA fragmentation. (A). Molt-4 cells were treated with DMSO or $1 \mu \mathrm{M}$ AHPN in the presence of Z-VAD-FMK at the concentrations indicated. After $24 \mathrm{~h}$ incubation total cell number, number of viable cells (Trypan blue-negative cells) and caspase-3-like activity were determined. The reduction in cell number was calculated as percent of the tota cell number of DMSO-treated cells $(\square)$. The number of viable cells for each condition was calculated as percent of total cell number $(\boldsymbol{\Delta})$. Protease activity was plotted as the percent of the activity present in AHPN-treated cells (no ZVAD-FMK) (O). (B). Molt-4 cells were treated for $24 \mathrm{~h}$ with DMSO (NA) or $1 \mu \mathrm{M}$ AHPN in the presence or absence of Z-VAD-FMK. Cells were collected and analyzed by TUNEL assay ment with these results, extracts from AHPN-treated Molt-4$\mathrm{Bcl}-2$ cells were unable to cleave tPARP (Figure 7B). The inhibitory effect of Bcl-2 was not limited to Molt-4 cells since expression of $\mathrm{Bcl}-2$ also prevented the increase in caspase-3-like activity by AHPN in S49-Bcl-2 cells (Figure 10B). Inhibition of apoptosis was also evident from analysis of DNA fragmentation, as Bcl-2 inhibited the induction of internucleosomal degradation in $549-\mathrm{Bcl}-2$ cells by AHPN (Figure 2).

Overexpression of $\mathrm{Bcl}-2$ also greatly inhibited the increase in annexin V-FITC binding induced by AHPN in Molt-4 cells (Figure 11). Our results demonstrate that overexpression of $\mathrm{Bcl}-2$ inhibits several molecular events associated with the AHPN-induced cell death pathway.

\section{Discussion}

In this study, we demonstrated that treatment of several T cell lymphoblastoma cell lines with the novel retinoid 6-[3-(1adamantyl)-4-hydroxyphenyl]-2-naphthalene carboxylic acid
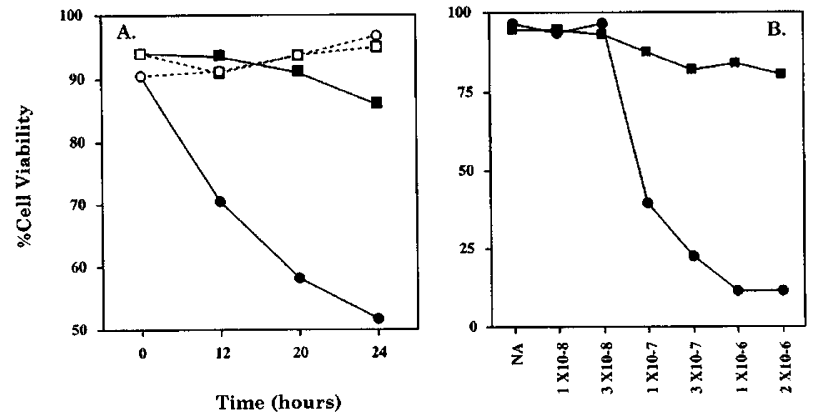

AHPN (M)

Figure $9 \mathrm{Bcl}-2$ inhibits the induction of cell death by AHPN in Molt-4 cells. A. Molt-4-neo and Molt-4-Bcl-2 were treated with AHPN $(1 \mu \mathrm{M})$ or DMSO $(0.1 \%)$ and at different time intervals the number of alive and dead cells determined by Trypan blue exclusion. The percent alive cells was calculated and plotted. DMSO- (0) and AHPN-treated Molt-4-neo cells (๑); DMSO- $(\square)$ and AHPN-

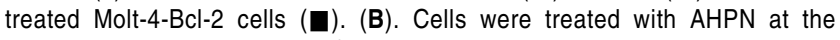
concentrations indicated and after $24 \mathrm{~h}$ cell survival was determined. $\boldsymbol{C}$, Molt4-neo cells; $\square$, Molt-4-Bcl-2 cells
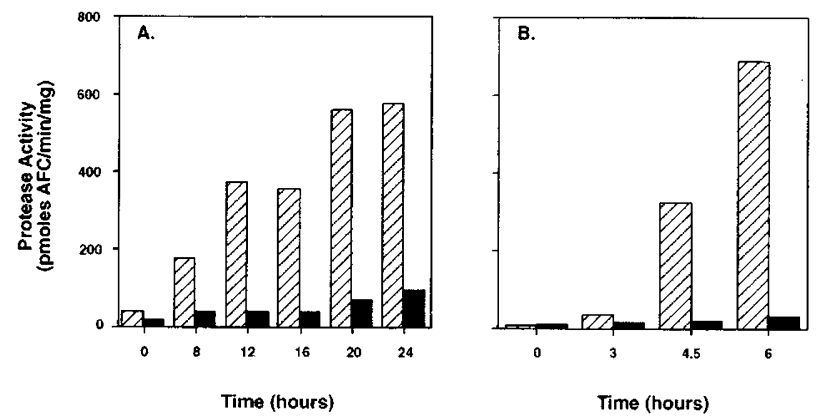

Figure $10 \mathrm{Bcl}-2$ inhibits the activation of caspase-3-like activity by AHPN in Molt- 4 and S49 cells. Cells were treated with AHPN $(1 \mu \mathrm{M})$ and at the indicated time points cells were harvested and DEVD-AFC cleavage activity measured in the corresponding lysates. (A). Molt-4 cells (hatched bars) and Molt-4-Bcl-2 (solid bars). (B). S49-neo cells (hatched bars) and S49-Bcl-2 cells (solid bars) 

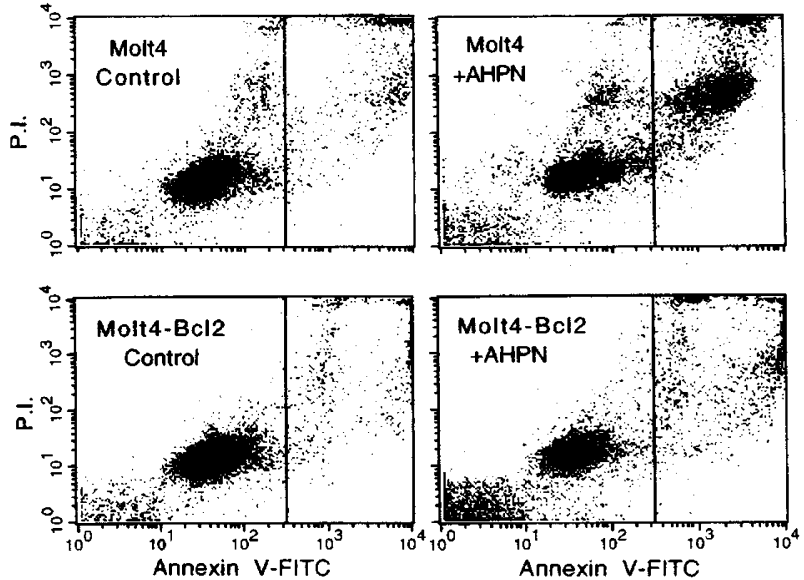

Figure $11 \mathrm{Bcl}-2$ inhibits the increase in annexin $\mathrm{V}$ binding by AHPN in Molt-4 cells. Molt-4-neo and Molt-4-Bcl-2 were treated with AHPN $(1 \mu \mathrm{M})$ or DMSO and after $17 \mathrm{~h}$ cells were harvested and analyzed for annexin V-FITC binding by flow cytometric analysis. Left panels, DMSO-treated cells; right panels, AHPN-treated cells. Top panels, Molt-4-neo; bottom panels, Molt-4-Bcl-2. Vertical axis indicates propidium iodide (PI) staining

(AHPN) caused growth arrest in the early S-phase of the cell cycle and induced apoptosis. The induction of apoptosis by AHPN was corroborated by the observed internucleosomal fragmentation of genomic DNA by 'ladder' or TUNEL assays, the increase in annexin $\mathrm{V}$ binding and the induction of caspase activity. Expression of Bcl-2 or the presence of the caspase inhibitor Z-VAD-FMK greatly reduced the rate of the execution of the apoptotic pathway but did not prevent the AHPN-induced cell cycle arrest or cell death. Our results suggest that AHPN triggers several parallel pathways that are involved in cell death.

AHPN has been shown to induce growth arrest and/or apoptosis in a number of carcinoma cell lines (Shao et al, 1995; Schadendorf et al, 1996; Oridate et al, 1997; Sun et al, 1997; Piedrafita and Pfahl, 1997; Hsu et al, 1997; Adachi et al, 1998). All-trans RA and a number of other retinoids that bind selectively to either the nuclear retinoid receptors RARs or RXRs, or exhibit selective anti-AP1 activity, did not affect proliferation of the lymphoma cell lines tested nor induced apoptosis or caspase activity. Although RT-PCR demonstrated expression of $\operatorname{RAR} \alpha, \beta$ and $\gamma$ and $\operatorname{RXR} \alpha$ and $\gamma$ mRNAs in Jurkat cells (Adachi $H$ and Jetten AM, unpublished observations), the specificity by which these retinoids induce apoptosis suggests that AHPN acts through a novel mechanism that appears not to involve either RAREor RXRE-dependent transactivation nor the anti-AP1 activity of retinoids (Shao et al, 1995; Sun et al, 1997; Piedrafita and Pfahl, 1997; Hsu et al, 1997; Adachi et al, 1998). This mechanism appears to be different from AHPN-induced apoptosis in thymocytes which is inhibited by $\operatorname{RAR} \alpha-$ selective retinoids and appears to be mediated by RAR $\gamma$ (Szondy et al, 1997). The mechanism of action of AHPN appears also different from that of 14-hydroxy-4,14-retroretinol which inhibits apoptosis in lymphocytes (O'Connell et al, 1996). It is possible that certain regulatory activities of retinoids are related to distinct conformation changes in the receptor as has been reported for the interactions of RA, 9-
cis-RA and the RAR $\alpha$-selective antagonist RO 41-5253 with RAR $\alpha$ (Keidel et al, 1997). The induction of apoptosis by AHPN could be related to a distinct conformational change in the $\operatorname{RAR} \gamma$ receptor that is unique for this retinoid. However, several observations appear not to support a requirement for $R A R \gamma$ in this action of AHPN. AHPN is a very effective inducer of apoptosis in promyelocytic leukemia HL-60 cells which do not express RAR $\gamma$ (Hsu et al, 1997). In addition, the RAR-selective retinoid TTAB which was unable to induce apoptosis, binds to RAR $\gamma$ with much greater affinity than AHPN and should be able to compete with AHPN for binding to this receptor and antagonize the induction of caspase activity by AHPN. However, no effect of TTAB on AHPN action was observed (Figure 6). It is interesting to note that the expression of several mRNAs regulated by AHPN identified thus far appears to be controlled at a posttranscriptional level (Shao et al, 1995; Adachi et al, 1998; Sakaue et al, unpublished observations). These observations suggest that regulation at the level of mRNA stability may play an important role in the AHPN signaling pathway leading to apoptosis. Future studies have to provide further insight into these mechanisms.

Activation of caspases has been demonstrated to play an important role in the induction of apoptosis in mammalian cells by a variety of signals (Nicholson, 1994; Fernandes-Alnemri et al, 1994; Kumar and Flavin, 1996). Our results show that in the T cell lymphoma cell lines tested, activation of caspase-3-like and to a smaller degree caspase-1-like activity is part of the AHPN-induced cell death pathway in agreement with other studies (Hsu et al, 1997; Piedrafita and Pfahl, 1997). In both Jurkat and Molt-4 cells the activation of caspase(s) occurred after a lag of several hours. To study the role of this caspase activity in the execution of AHPN-induced apoptosis, the effect of the cell-permeable caspase inhibitor Z-VAD-FMK was examined. Treatment of Molt-4 cells with Z-VAD-FMK very effectively blocked the induction of caspase activity and DNA fragmentation by AHPN, and although the presence of Z-VAD-FMK slowed down cell death, it did not prevent it. In addition, the presence of Z-VAD-FMK had little effect on the inhibition of cell growth by AHPN or the accumulation of cells in the S-phase of the cell cycle. These results indicate that activation of caspase-3 accelerates the execution of AHPN-induced apoptosis and that other parallel events are sufficient to cause cell death.

A recent study (Thornberry et al, 1997) has defined the optimal specificities of a series of caspases. Z-VAD-FMK at high concentrations can inhibit many caspases, including caspase-1-like and caspase-3-like activity (Stefanis et al, 1996; McCarthy et al, 1997; Longthorne and Williams, 1997). Z-VAD-FMK has been reported to be able to inhibit several aspects of the apoptotic pathway; however, the effects on apoptosis are dependent on the type of signal and cell line tested. Both DNA fragmentation and phosphatidylserine externalization has been reported to require caspase activation and are inhibited by Z-VADFMK (Martin et al, 1996; Amstrong et al, 1996; Dubrez et al, 1996; Figure 8). Caspase inhibitors have been demonstrated to prevent Fas-induced apoptosis in Jurkat 
cells; these cells also retain their proliferative ability (Longthorne and Williams, 1997). In contrast, Z-VADFMK blocked caspase activity, the increase in annexin $\mathrm{V}$ binding and DNA fragmentation in AHPN-treated lymphoma cells but did not prevent their accumulation in the $S$ phase of the cell cycle nor their cell death. A dissociation between caspase activation and growth arrest or apoptosis has been observed in several other cell systems (Slee et al, 1996; Stefanis et al, 1996; McCarthy et al, 1997; Monney et al, 1997). In PC12 cells, the inhibition of caspase activity by Z-VAD-FMK could be dissociated from its ability to inhibit cell death (Stefanis et al, 1996). In addition, inhibition of caspase activity by Z-VAD-FMK did not prevent cell death induced by oncogenes, DNA damage or the $\mathrm{Bcl}-2$ homologue Bak in rat fibroblasts (McCarthy et al, 1997) or Bax-induced cell death in Jurkat cells (Xiang et al, 1996). These studies showed that ZVAD-FMK prevented chromatin condensation, internucleosomal fragmentation, cleavage of PARP and externalization of phosphatidylserine. However, under these conditions surface blebbing and dramatic vacuolation still occurred. Moreover, in Bax-induced apoptosis Z-VAD-FMK did not prevent the reduction in mitochondrial potential. Whether such events still take place in cells treated simultaneously with AHPN and Z-VAD-FMK is being investigated. These observations suggest that although activation of caspases play an important role in carrying out at least part of the apoptotic process, cell death can occur independently from the activation of caspases inhibited by Z-VAD-FMK. Although the involvement of (an)other protease(s) cannot be ruled out, the specificity of such a putative protease should be different from that of caspase-1- and -3-like caspases. Recently, cathepsin D has been implicated in apoptosis suggesting a role for other proteases in this process (Deiss et al, 1996).

$\mathrm{Bcl}-2$ has been demonstrated to play an important role in the regulation of apoptosis and to inhibit the induction of apoptosis in lymphocytes by a variety of signals (Hockenbery et al, 1990; Miyashita and Reed, 1992). Recent studies have shown that it plays a critical role in controlling the activation of caspases by regulating the release of cytochrome $c$ from mitochondria indicating that $\mathrm{Bcl}-2$ functions upstream of the caspase activation step in the cell death pathway (Kluck et al, 1997; Yang et al, 1997). In this study, we show for the first time that expression of $\mathrm{Bcl}-2$ can inhibit the induction of caspase-3-like activity and apoptosis by AHPN. However, $\mathrm{Bcl}-2$ did not reverse the inhibition of cell proliferation by AHPN and had little effect on accumulation of cells in the Sphase of the cell cycle. These results indicate that growth arrest can be uncoupled from apoptosis and that AHPNinduced growth arrest can occur independent of $\mathrm{Bcl}-2$ action. AHPN had little effect on the hyperphosphorylation of $\mathrm{Rb}$ or the level of cyclin A in Molt-4 cells consistent with growth arrest in S-phase (Adachi $\mathrm{H}$ and Jetten AM, unpublished observations). These results contrast the reduction in $\mathrm{Rb}$ hyperphosphorylation and cyclin A levels associated with the G1-growth arrest observed in AHPN-treated lung and mammary carcinoma cells (Shao et al, 1995; Adachi et al, 1998). Why AHPN causes in different cell types growth arrest at different stages of the cell cycle has yet to be elucidated.
In summary, we demonstrated that AHPN is an effective inducer of apoptosis in a variety of $\mathrm{T}$ cell lymphoma cell lines. Induction of caspase-3-like activity plays an important role in the execution of AHPN-induced apoptosis but cells can undergo cell death in the absence of this activity suggesting that AHPN-induced cell death involves caspasedependent and independent mechanisms. This action of AHPN appears to occur through a novel mechanism not involving RAR receptors and is therefore different from the RAR $\gamma$-dependent mechanism observed in thymocytes (Szondy et al, 1997). Future studies have to determine whether AHPN mediates its action through another receptor or binding protein. A recent study has shown that several derivatives of AHPN can inhibit growth of lung carcinomas in mice (Lu et al, 1997) indicating that this retinoid may be useful in cancer therapy and possibly in the treatment of lymphoblastoma as well. Elucidation of the AHPN-signaling pathway may lead to the development of new analogs with higher efficacy.

\section{Materials and Methods}

\section{Materials}

The retinoid 6-[3-(1-adamantyl)-4-hydroxyphenyl]-2-naphthalenecarboxylic acid (AHPN/CD437) was described previously (Delescluse et al, 1991) and obtained from Dr. U. Reichert (CIRD Galderma, Valbonne, France). The RAR- (SRI-6751-84/TTAB, 4-(5,6,7,8tetrahydro-5,5,8,8-tetramethyl-2-anthracenyl)benzoic acid), RXR(SR11217, 4-[1-(5,6,7,8-tetrahydro-5,5,8,8,-tetramethyl-2-naphthalenyl)-2-methylpropenyl]benzoic acid), and anti-AP1-selective (SR11302, (E)-3-methyl-9-(2,6,6-trimethylcyclohexenyl)-7-(4-methylphenyl)-2,4,6,8-nonatetraenoic acid) retinoids were provided by $\mathrm{Dr}$. M. Dawson (Fanjul et al, 1994). All-trans retinoic acid was obtained from Hoffmann-La Roche, Nutley, NJ, USA. Retinoids were dissolved in DMSO. Control cells received DMSO only.

\section{Cell Culture}

Human T cell lymphoma Jurkat (clone E6-1) and rat T cell lymphoma S49-neo and S49-bcl2 (Miyashita and Reed, 1992) were obtained from Drs Jeff Webster and Carl Bortner, NIEHS. Human T cell lymphoma Molt-4 and Molt-4-bcl2 were described previously (Zhang et al, 1996). All cells were cultured in RPMI-1640 medium supplemented with $10 \%$ heat-inactivated fetal bovine serum, $2 \mathrm{mM}$ L-glutamine, 100 units penicillin and $100 \mu \mathrm{g}$ streptomycin (complete media). The T-cell hybridoma cell line D011.10 was provided by Dr. B.A. Osborne (University of Massachusetts, Amherst, MA, USA) and grown in RPMI1640 medium supplemented with $10 \%$ horse serum.

\section{MTT assay}

Cells $\left(1.0 \times 10^{6}\right.$ cells $\left./ \mathrm{ml}\right)$ were plated in 24 well dishes $(0.5 \mathrm{ml} /$ well $)$ and treated with and without AHPN as indicated. The 3-(4,5dimethylthiazol-2yl)-2,5-diphenyl tetrazolium bromide (MTT) assay (Boehringer Mannheim) was used to analyze cell proliferation and viability. MTT solution $(100 \mu \mathrm{l})$ was added to the cell suspensions at a final concentration of $0.5 \mathrm{mg} / \mathrm{ml}$. After incubation for $1 \mathrm{~h}$ at $37^{\circ} \mathrm{C}$, $0.5 \mathrm{ml}$ solubilization buffer was added and $24 \mathrm{~h}$ later the absorbance measured at 575 and $690 \mathrm{~nm}$. The difference between these two values is a measurement for cell survival. 


\section{DNA fragmentation assay}

Untreated cells and cells treated with $1 \mu \mathrm{M}$ AHPN for $8 \mathrm{~h}$ were collected by centrifugation. Cells were washed once in cold PBS, resuspended in $100 \mu$ lysis buffer $A$ ( $50 \mathrm{mM}$ Tris- $\mathrm{HCl} \mathrm{pH} \mathrm{8.0,10} \mathrm{mM}$ EDTA, $0.5 \%$ sodium laurel sarcosine and $1.8 \mathrm{mg} / \mathrm{ml}$ proteinase $\mathrm{K}$ (Boehringer Mannheim) and incubated overnight at $50^{\circ} \mathrm{C}$. Then $50 \mu \mathrm{l}$ of RNase (RPA grade; $1 \mathrm{mg} / \mathrm{ml}$, Ambion, Austin, Texas, USA) was added and the mixture incubated for an additional two hours at $37^{\circ} \mathrm{C}$. After the addition of $10 \times$ loading buffer $(50 \%$ glycerol, $0.006 \%$ bromophenol blue, $0.006 \%$ xylene cyanol FF), the DNA sample was electrophoresed in 1\% agarose gel with $1 \times$ TBE buffer as described (Zhang et al, 1995). DNA ladders were visualized by ethidium bromide staining.

\section{Flow cytometric analysis}

TUNEL assay. Jurkat cells $\left(1 \times 10^{5} / 100-\mathrm{mm}\right.$ dish) were plated in complete RPMI1640 medium and 2 days later treated with $1.0 \mu \mathrm{M}$ AHPN for $8 \mathrm{~h}$. Flow cytometric analysis of DNA fragmentation was performed using a variation of the nick end-labeling technique of Gavrielli as described (Gavrieli et al, 1992), substituting dUTPfluorescein isothiocyanate (FITC) for biotinylated dUTP in the labeling reaction. Briefly, the cell pellets were washed with cold PBS and fixed with $1 \%$ paraformaldehyde in PBS for $15 \mathrm{~min}$. The cell pellet was washed in PBS, permeabilized using $70 \%$ ethanol, washed again in PBS containing $1 \%$ bovine serum albumin, and labeled. Cell samples were divided into two halves. One half was used to determine background fluorescence by omitting the terminal deoxynucleotidyltransferase enzyme (TdT) from the reaction mixture. TdT was added to the second half of the sample and increases in fluorescence (FL1) were evaluated by flow cytometric analysis. Analyses were carried out with the Flow Cytometric Analysis Reagent Set (Boehringer Mannheim). Clumps and doublets were excluded from the analysis by gating on forward scatter versus propidium iodide (PI) fluorescence (FL2-width). Flow cytometric analysis was performed with a Becton Dickinson FACSort and accompanying CellQuest software.

$\mathrm{BrdU}$ analysis. For the analysis of BrdU incorporation and $\mathrm{PI}$ labeling, cells were pulse-labeled for $30 \mathrm{~min}$ with $10 \mathrm{mM}$ BrdU, washed in ice-cold PBS and pelleted. Cell pellets were resuspended in PBS and cells fixed in ice-cold ethanol as described previously (Adachi et al, 1998). Incorporation of BrdU was measured using an FITC-conjugated anti-BrdU antibody (Becton Dickinson) and the Flow Cytometric Reagent Set.

Annexin V binding. AHPN-treated and untreated cells were collected by centrifugation and washed once with cold PBS. The analysis of annexin $\mathrm{V}$ binding was carried out using the TACS ${ }^{\mathrm{TM}}$ Annexin V-FITC kit from TREVIGEN (Gaithersburg MD, USA) according to the manufacturer's instructions. Cells were resuspended, divided equally over four eppendorf tubes and then centrifuged. After removing the supernatant, each cell pellet was gently resuspended in $100 \mu \mathrm{l}$ of binding reagent with or without propidium iodide and/or annexin $\mathrm{V}$ FITC and incubated at room temperature in the dark. After $15 \mathrm{~min}$, $400 \mu \mathrm{l}$ of $1 \mathrm{X}$ binding buffer was added and samples analyzed by flow cytometry.

\section{Caspase fluorogenic enzyme assay}

Cells treated with AHPN and untreated cells $\left(3 \times 10^{7}\right.$ cells each) were harvested by centrifugation and then lysed on ice for $3 \mathrm{~min}$ in $100 \mu \mathrm{l}$
$10 \mathrm{mM} \mathrm{MgCl}, 0.25 \%$ NP-40 (lysis buffer B). Cell debris was removed by centrifugation at $213000 \times g$ in a TL-100 centrifuge for $30 \mathrm{~min}$ at $4^{\circ} \mathrm{C}$. The caspase-1-like and caspase-3-like activity in the supernatants were measured by a fluorometric assay (). All peptides were purchased from Biomol, Plymouth Meeting, PA, USA. Enzyme assays contained $30 \mu \mathrm{l}$ of supernatant and $50 \mu \mathrm{M}$ Asp-Glu-Val-Asp-7-amino4-trifluoromethyl coumarin (DEVD-AFC) or Tyr-Val-Ala-Asp-7-amino4-trifluoromethyl coumarin (YVAD-AFC) substrate in buffer $(50 \mathrm{mM}$ HEPES, $10 \%$ sucrose, $0.1 \%$ CHAPS, $100 \mathrm{mM}$ DTT, pH 7.5) with or without $12.5 \mu \mathrm{M}$ of the reversible inhibitor N-acetyl-Asp-Glu-Val-Aspaldehyde (DEVD-CHO) or Tyr-Val-Ala-Asp-aldehyde (YVAD-CHO), respectively. Samples were incubated at $30^{\circ} \mathrm{C}$, and after 5 and $65 \mathrm{~min}$ their fluorescence were measured at $505 \mathrm{~nm}$ (excitation $400 \mathrm{~nm}$ ) using a Perkin Elmer 650-40 Fluorescence Spectrophotometer. A standard curve of fluorescence vs free AFC (Sigma Chemical Co., St. Louis, MO, USA) was used to calculate the specific caspase activity. The cell-permeable, irreversible caspase inhibitor benzyloxycarbonylVal-Ala-Asp fluoromethylketone (Z-VAD-FMK) was used to study the effects of caspase inhibition on the cell death pathway in cultured cells. Cells were washed extensively to remove free Z-VAD-FMK before cellular extracts were prepared.

\section{Poly(ADP-ribose)polymerase (PARP)-cleavage assay}

A PET15 vector containing a cDNA encoding the first 338 amino acid $\mathrm{N}$-terminal region of PARP including the caspase- 3 cleavage site, was obtained from Dr J Collier (Harvard University). The TNT-coupled reticulocyte lysate system (Promega) in combination with T7 polymerase and ${ }^{35}$ S-methionine (Dupont NEN) was used to synthesize radiolabeled $48 \mathrm{kD}$ truncated PARP (tPARP). The radiolabeled products were incubated with cellular extracts $(5 \mu \mathrm{g}$ protein) in buffer $\mathrm{C}(100 \mathrm{mM}$ Hepes $\mathrm{pH} 7.5,10 \%$ sucrose, $0.1 \%$ CHAPS, $10 \mathrm{mM}$ DTT) at $37^{\circ} \mathrm{C}$ for different time periods. The reaction was stopped by the addition of sample buffer. Samples were subsequently analyzed by SDS-polyacrylamide electrophoresis. The gel was dried and autoradiography performed.

\section{Acknowledgements}

The authors like to thank Dr. C. Bortner for his assistance with the flow cytometric analysis and Drs. D. Swope and C. Bortner for their comments on the manuscript.

\section{References}

Adachi H, Preston G, Harvat B, Dawson MI and Jetten AM (1998) Inhibition of cell proliferation and induction of apoptosis by the retinoid AHPN in human lung carcinoma cellls. Am. J. Respir. Cell. Mol. Biol. 18: 323-333

Amstrong RC, Aja T, Xiang J, Gaur S, Krebs JF, Hoang K, Bai X, Korsmeyer SJ, Karanewsky DS, Fritz LC and Tomaselli KJ (1996) Fas-induced activation of the cell death-related protease CPP32 is inhibited by Bcl-2 and by ICE family protease inhibitors. J. Biol. Chem. 271: 16850-16855

Bissonnette RP, Brunner T, Lazarchik SB, Yoo NJ, Boehm MF, Green DR and Heyman RA (1995) 9-cis retinoic acid inhibition of activation-induced apoptosis is mediated via regulation of fas ligand and requires retinoic acid receptor and retinoid X receptor activation. Mol. Cell. Biol. 15: 5576-5585

Boise LH, Gottschalk AR, Quintans J and Thompson CB (1995) Bcl-2 and Bcl-2related proteins in apoptosis regulation. Curr. Top. Microbiol. Immunol. 200: $107-121$

Buck J, Derguini F, Levi E, Nakanishi K and Hammerling U (1991) Intracellular signaling by 14-hydroxy-4,14-retro-retinol. Science 254: 1654-1656 
Caron-Leslie LM, Evans RB and Cidlowski JA (1994) Bcl-2 inhibits glucocorticoidinduced apoptosis but only partially blocks calcium ionophore or cycloheximideregulated apoptosis in S49 cells. FASEB J. 8: 639-645

Chauhan D, Pandey P, Ogata A, Teoh G, Krett N, Halgren R, Rosen S, Kufe D, Kharbanda S, Anderson K (1997) Cytochrome c-dependent and -independent induction of apoptosis in multiple myeloma cells. J. Biol. Chem. 272: 2999529997

Deiss LP, Galinka H, Berissi H, Cohen O and Kimchi A (1996) Cathepsin D protease mediates programmed cell death by interferon- $\gamma$, Fas/APO- 1 and TNF- $\alpha$. EMBO J. $15: 3861-3870$

Delescluse C, Cavey MT, Martin B, Bernard BA, Reichert U, Maignan J, Darmon M and Shroot B (1991) Selective high affinity RA receptor $\alpha$ or $\beta-\gamma$ ligands. Mol. Pharmacol. 40: 556-562

Dubrez L, Savoy I, Hamman A and Solary E (1996) Pivotal role of a DEVD-sensitive step in etoposide-induced and Fas-mediated apoptotic pathways. EMBO J. 15: 5504-5512

Enari M, Talanian RV, Wong WW and Nagata S (1996) Sequential activation of ICElike and CPP32-like proteases during Fas-mediated apoptosis. Nature 380 $723-726$

Fanjul A, Dawson MI, Hobbs PD, Jong L, Cameron JF, Harlev E, Graupner G, Lu XP and Pfahl M (1994) A new class of retinoids with selective inhibition of AP-1 inhibits proliferation. Nature 372: 107-111

Fernandes-Alnemri T, Litwack G and Alnemri ES (1994) CPP32, a novel human apoptotic protein with homology to Caenorhabditis elegans cell death protein Ced-3 and mammalian interleukin-1 $\beta$-converting enzyme. J. Biol. Chem. 269: 30761-30764

Gavrieli Y, Sherman Y and Ben-Sasson SA (1992) Identification of programmed cell death in situ via specific labeling of nuclear DNA fragmentation. J. Cell Biol. 119: $493-501$

Giguère V (1994) RA receptors and cellular retinoid binding proteins: complex interplay in retinoid signaling. Endocrine Rev. 15: 61-79

Hockenbery D, Nunez G, Milliman C, Schreiber RD and Korsmeyer SJ (1990) Bcl-2 is an inner mitochondrial membrane protein that blocks programmed cell death. Nature 348: $334-336$

Hsu CA, Rishi AK, Su-Li X, Gerald TM, Dawson MI, Schiffer C, Reichert U, Shroot B, Poirer GC and Fontana JA (1997) Retinoid induced apoptosis in leukemia cells through a retinoic acid nuclear receptor-independent pathway. Blood 89: 4470 4479

Iwata M, Mukai M, Nakai Y and Iseki R (1992) Retinoic acid inhibit activation-induced apoptosis in T cell hybridomas and thymocytes. J. Immunol. 149: 3302-3308

Jacobson MD, Weil M and Raff MC (1997) Programmed cell death in animal development. Cell 88: 347-354

Keidel S, Lamour FPY and Apfel CM (1997) Mutational analysis reveals that all-transretinoic acid, 9-cis-retinoic acid and antagonist interact with distinct binding determinants of RAR $\alpha$. J. Biol. Chem. 272: 18267-18272

Kluck RM, Bossy-Wetzel E, Green DR and Newmeyer DD (1997) The release of cytochrome c from mitochondria: a primary site for $\mathrm{Bcl}-2$ regulation of apoptosis. Science 275: 1132-1136

Korsmeyer SJ (1995) Regulators of cell death. Trends Genet. 11: 101-105

Kroemer G (1997) The proto-oncogene Bcl-2 and its role in regulating apoptosis. Nat. Med. 3: $614-620$

Kumar S and Flavin MF (1996) The ICE family of cysteine proteases as effectors of cell death. Cell Death Differ. 3: 255-267

Lomo J, Smeland EB, Ulven S, Natarajan V, Blomhoff R, Gandhi U, Dawson MI, Blomhoff HK (1998) RAR-, not RXR, ligands inhibit cell activation and prevent apoptosis in B-lymphocytes. J. Cell. Physiol. 175: 68-77

Longthorne VL and Williams GT (1997) Caspase activity is required for commitment to Fas-mediated apoptosis. EMBO J. 16, 3805-3812

Lu XP, Fanjul A, Picard N, Pfahl M, Rungta D, Nared-Hood K, Carter B, Piedrafita J, Tang S, Fabbrizio E and Pfahl M (1997) Novel retinoid-related molecules as apoptosis inducers and effective inhibitors of human cancer cells in vivo. Nat. Genet. 3: $686-690$

Martin SJ, Finucane DM, Amarante-Mendes GP, O'Brien GA and Green DR (1996) Phosphatidylserine externalization during CD95-induced apoptosis of cells and cytoplasts requires ICE/CED-3 protease activity. J. Biol. Chem. 271: 28753 28756

McCarthy NJ, Whyte MKB, Gilbert CS and Evan GI (1997) Inhibition of CED-3/ICErelated proteases does not prevent cell death induced by oncogenes, DNA damage or the Bcl-2 homologue Bak. J. Cell Biol. 136: 215-227
Miyashita T and Reed JC (1992) Bcl-2 transfer increases relative resistance of S49.1 and WEHI7.2 lymploid cells to cell death and DNA fragmentation induced by glucocorticoids and multiple chemotherapeutic drugs. Cancer Res. 52: 54075411

Monney L, Otter I, Olivier R, Ozer HL, Haas AL, Omura S and Borner C (1997) Defects in the ubiquitin pathway induce caspase-independent apoptosis blocked by Bcl2. J. Biol. Chem. 273:6121-6131

Mountz JD, Zhou T, SuX, Wu J and Cheng J (1996) The role of programmed cell death as an emerging new concept for the pathogenesis of autoimmune diseases. Clin. Immunol. Immunopathol. 80: S2-S14

Nicholson DL (1994) Identification and inhibition of the ICE/CED-3 protease necessary for mammalian apoptosis. Nature 376: 37-43

O'Connell MJ, Chua R, Hoyos B, Buck J, Chen Y, Derguini F and Hammerling U (1996) Retro-retinoids in regulated cell growth and death. J. Exp. Med. 184:549555

Oridate N, Higuchi M, Suzuki S, Shroot B, Hong WK and Lotan R (1997) Rapid induction of apoptosis in human C33 cervical carcinoma cells by the synthetic retinoid 6-[3-(1-adamantyl)hydroxyphenyl]-2-naphtalene carboxylic acid (CD437). Int. J. Cancer 70: 484-487

Piedrafita FJ and Pfahl M (1997) Retinoid-induced apoptosis and Sp-1 cleavage occur independently of transcription and require caspase activation. Mol. Cell. Biol. 17: 6348-6358

Reed JC (1997) Double identity for proteins of the Bcl-2 family. Nature 387: 773-776

Schadendorf D, Kern MA, Artuc M, Pahl HL, Rosenbach T, Fichtner I, Nurnberg W, Stuting S, von Stebut E, Worm M, Makki A, Jurgovsky K, Kolde G and Henz BM (1996) Treatment of melanoma cells with the synthetic retinoid CD437 induces apoptosis via activation of AP-1 in vitro, and causes growth inhibition in xenographs in vivo. J. Cell Biol. 135: 1889-1898

Shao ZM, Dawson MI,. Li XS, Rishi AK, Sheikh MS, Han QX, Ordonez JV, Shroot B and Fontana JA (1995) p53 independent G0/G1 arrest and apoptosis induced by a novel retinoid in human breast cancer cells. Oncogene 11: 493-504

Slee EA, Zhu H, Chow SC, MacFarlane M, Nicholson DW and Cohen GM (1996) Benzyloxycarbonyl-val-ala-asp (OMe) fluoromethylketone (Z-VAD.FMK) inhibits apoptosis by blocking the processing of CPP32. Biochem J. 315: 21-24

Smith CA, Williams GT, Kingston R, Jenkinson EJ and Owen JJT (1989) Antibodies to CD3/T-cell receptor complex induce death by apoptosis in immature T cells in thymic cultures. Nature 337: 181-184

Stefanis L, Park DS, Yan CYI, Farinelli SE, Troy CM, Shelanski ML and Greene LA (1996) Induction of CPP32-like activity in PC12 cells by withdrawal of trophic support. Dissociation from apoptosis. J. Biol. Chem. 271: 30663-30671

Sun SY, ShrootB, Hong WK and Lotan R (1997) Induction of apoptosis in human nonsmall cell lung carcinoma cells by the novel synthetic retinoid CD437. J. Cell. Physiol. 173: 279-284

Szondy Z, Reichert U, Bernardon JM, Michel S, Toth R, Ancian P, Ajzner E and Fesus $L$ (1997) Induction of apoptosis by retinoids and retinoic acid receptor gammaselective compounds in mouse thymocytes through a novel apoptosis pathway. Mol. Pharmacol. 51: $972-982$

Tewari M, Quan LT, O'Rourke K, Desnoyers S, Zeng Z, Beidler DR, Poirier GG, Salvesen GS and Dixit VM (1995) Yama/CPP32, a mammalian homolog of CED3 , is a CrmA-inhibitable protease that cleaves the death substrate poly(ADPribose) polymerase. Cell 81: 1-20

Thompson, CB (1995) Apoptosis in the pathogenesis and treatment of disease. Science 267: 1456-1462

Thornberry NA, Rano TA, Peterson EP, Rasper DM, Timkey T, Garcia-Calvo M, Houtzager VM, Nordstrom PA, Roy S, Vaillancourt JP, Chapman KT and Nicholson DW (1997) A combinatorial approach defines specificities of members of the caspase family and granzyme B. J. Biol. Chem. 272: 1790717911

Ucker DS (1987) Cytotoxic T lymphocytes and glucocorticoids activate an endogenous suicide process in target cells. Nature 327: 62-64

Vacchio MS and AshwellJD (1993) 9-cis-retinoic acid inhibits activation-driven T-cell apoptosis: implications for retinoid $X$ receptor involvement in thymocyte development. Proc. Natl. Acad. Sci. USA 90: 6170-6174

Vermes I, Haanen C, Steffens-Nakken H and Reutelingsperger C (1995) A novel assay for apoptosis. Flow cytometric detection of phosphatidylserine expression on early apoptotic cells using fluorescein labelled annexin V. J. Immunol. Methods 184: $39-51$

Webb SJ, Harrison DJ and Wyllie AH (1997) Apoptosis: an overview of the process and its relevance in disease. Adv. Pharmacol. 41: 1-34 
Xiang J, Chao DT and Korsmeyer SJ (1996) Bax-induced cell death may not require interleukin $1 \beta$-converting enzyme-like proteases. Proc. Natl. Acad. Sci. USA 93: $14559-14563$

Yang J, Liu X, Bhalla K, Kim CN, Ibrado AM, Cai J, Peng T-I, Jones DP and Wang X (1997) Prevention of apoptosis by Bcl-2: release of cytochrome $\mathrm{C}$ from mitochondria blocked. Science 275: 1129-1131

Yang Y, Mercep M, Ware CF and Ashwell JD (1995a) Fas and activation-induced Fas ligand mediate apoptosis of T cell hybridomas: inhibition of Fas ligand expression by retinoic acid and glucocorticoids. J. Exp. Med. 181: 1673-1682

Yang Y, Minucci S, Ozato K, Heyman RA and Ashwell JD (1995b) Efficient inhibition of activation-induced Fas ligand up-regulation and $T$ cell apoptosis by retinoids requires occupancy of both retinoid $X$ receptors and retinoic acid receptors. J. Biol. Chem. 270: 18672-18677
Zhang J, Alter N, Reed JC, Borner C, Obeid LM and Hannun YA (1996) Bcl-2 interrupts the ceramide-mediated pathway of cell death. Proc. Natl. Acad. Sci. USA 93: $5325-5328$

Zhang L-X and Jetten AM (1997) Retinoids and apoptosis. In: Advances in Organ Biology (Ed) Sherbet GV and Bittar EE JAI Press Vol.3. pp. 161-196

Zhang L-X, Mills KJ, Dawson MI, Collins SJ and Jetten AM (1995) Evidence for the involvement of $R A$ receptor $R A R \alpha$-dependent signaling pathway in the induction of tissue transglutaminase and apoptosis by retinoids. J. Biol. Chem. 270:6022 6029 